\title{
Perubahan Dan Prediksi Penggunaan Lahan Menggunakan Markov - Cellular Automata di Kota Batu
}

\author{
Land Use Change and Prediction Using Markov - Cellular Automata \\ in Batu City
}

\section{Fahrizal Kreshna Yudichandra' ${ }^{1}$, Widiatmaka ${ }^{2}$ and Syaiful Anwar ${ }^{2}$}

Diterima: 7 Januari 2019 Disetujui: 26 Juni 2019

\begin{abstract}
Abstrak: Seiring dengan perkembangannya Kota Batu sebagai kota wisata, dikhawatirkan akan terjadi peningkatan alih fungsi lahan dari lahan kebun apel maupun lahan pertanian lain menjadi lahan permukiman dan pariwisata. Laju perubahan penggunaan lahan perlu dikendalikan agar lingkungan hidup tetap terjaga dan berkelanjutan. Salah satu upaya yang dapat dilakukan adalah dengan mengidentifikasi perubahan penggunaan lahan yang terjadi beberapa tahun sebelumnya. Tujuan penelitan ini adalah mendelineasi penggunaan lahan di Kota Batu tahun 2006, 2012 dan 2018 serta pola perubahannya dan memprediksi penggunaan lahan di Kota Batu tahun 2030. Prediksi penggunaan lahan dilakukan menggunakan pendekatan model Markov - Cellular Automata. Hasil analisis menunjukkan bahwa terjadi penurunan luas hutan sebesar $5 \%$ dan terjadi peningkatan luasan lahan terbangun sebesar $5,2 \%$ dari tahun 2006 hingga 2018. Prediksi perubahan lahan tahun 2030 menunjukkan akan terjadi penurunan luas hutan, lahan pertanian, dan lahan terbuka, serta terjadi peningkatan luas semak/belukar dan lahan terbangun. Lahan pertanian perlu diarahkan untuk dilindungi atau dikonservasi, sementara semak/belukar dan lahan terbuka perlu diarahkan menjadi lahan potensial untuk pengembangan kebun apel di Kota Batu.
\end{abstract}

Kata kunci: kebun apel, kota wisata, lahan pertanian, pola perubahan penggunaan lahan

Abstract: Along with the development of Batu City as a tourist city, it is feared that there will be an increase in land use conversion from apple orchards and other agricultural land into residential and tourism land. The rate of land use change must be controlled to maintain environment sustainability. One of the effort is studying the change that occurred in the past few years. The purpose of this study were to observe land use change pattern that occured in 2006, 2012, and 2018, and to predict the land use at 2030 in Batu City. Land use prediction was evaluated with Markov - Cellular Automata models. The analysis showed that forest area decreased up to $5 \%$ and the built area increased up to $5.2 \%$ from 2006 to 2018 . Prediction of land use in 2030 showed that there will be a decrease in forest, agriculture, and bareland areas, and an increase in shrubs and built areas. Agricultural land needs to be directed to be protected or conserved, while shrubs and open land need to be directed into potential land for apple orchards development in Batu City.

Keywords: agricultural land, apple orchards, land use change pattern, tourist city

\footnotetext{
${ }^{1}$ Program Studi Perencanaan Wilayah, Sekolah Pasca Sarjana, Institut Pertanian Bogor

${ }^{2}$ Departemen Ilmu Tanah dan Sumber Daya Lahan, Fakultas Pertanian, Institut Pertanian Bogor
} 


\section{PENDAHULUAN}

Pola perubahan penggunaan lahan cenderung dinamis dan memiliki kecepatan perubahan yang berbeda di setiap wilayah. Hal ini dikarenakan perubahan yang terjadi sangat tergantung pada faktor pendorongnya. Faktor tersebut terbagi dalam dua kategori, yaitu kondisi bio-fisik dan kondisi sosial-ekonomi. Faktor bio-fisik tidak mempengaruhi secara langsung, kebanyakan hanya menyebabkan terjadinya perubahan pada tutupan lahan atau mempengaruhi keputusan pengelolaan terhadap lahan tersebut yang merupakan aktivitas manusia. Seiring dengan semakin meningkatnya aktivitas manusia pada berbagai sektor terutama ekonomi, maka kebutuhan/permintaan akan sumberdaya lahan juga akan meningkat. Ketersediaan lahan yang relatif tetap menyebabkan tingginya kompetisi penggunaan lahan, namun pada akhirnya prioritas perubahan penggunaan lahan akan dimenangkan oleh desakan kebutuhan ekonomi dan sosial. Akibat dari desakan yang sangat kuat, diperlukan pengedalian laju perubahan penggunaan lahan agar keberlanjutan lingkungan dapat tetap terjaga. Salah satu upaya untuk menjaga keberlanjutan lingkungan adalah dengan mempelajari perubahan penggunaan lahan yang terjadi. McConnel (2001) menjelaskan bahwa studi perubahan penggunaan lahan tidak hanya mengalokasikan sejumlah penggunaan lahan tapi juga mempelajari variasi pola penggunaan lahan tersebut, sehingga ada proses monitoring terhadap penggunaan lahan.

Terdapat banyak cara dalam mempelajari perubahan penggunaan lahan, diantaranya adalah Markov-Cellular Automata. Konsep Cellular Automata (CA) pada mulanya diperkenalkan oleh Ulam dan Neumann sekitar tahun 1940-an yang menyediakan kerangka untuk menginvestigasi perilaku sistem yang kompleks (Yu et al., 2010). Metode ini merupakan sistem dinamis yang beroperasi dengan ruang dalam data raster dimana nilai data raster tersebut dapat didefinisikan ke dalam data binari atau diskrit dan perilakunya dipengaruhi oleh ketetanggaan (neigborhood). Model Markov-CA merepresentasikan penggunaan lahan dimana perubahannya tergantung pada aturan mempertimbangkan penggunaan lahan tetangganya (Manson, 2006). Chen et al. (2002) menjelaskan komponen utama Markov-CA adalah piksel (cell), state, ketetanggaan, dan fungsi perubahan (transition function atau transition rule).

Kota Batu dikenal sebagai daerah penghasil apel di Jawa Timur. Namun, seiring dengan perkembangannya sebagai kota wisata, dikhawatirkan akan terjadi peningkatan alih fungsi lahan dari lahan kebun apel maupun lahan pertanian lainnya menjadi lahan permukiman dan pariwisata. Kota Batu juga merupakan aset wisata utama di Jawa Timur yang berskala nasional hingga internasional. Kota Batu memiliki potensi pariwisata yang besar, baik wisata alam, buatan, maupun budaya. Potensi pariwisata kota Batu antara lain wisata alam pegunungan, wisata taman rekreasi, serta hotel dan wisata perbelanjaan. BPS Kota Batu (2017) mencatat bahwa objek wisata di Kota Batu jumlahnya meningkat tiga kali lipat pada tahun 2016 menjadi 25 objek wisata.

Peningkataan tiga kali lipat jumlah objek wisata Kota Batu hingga tahun 2016 menggambarkan secara tidak langsung adabya beberapa perubahan penggunaan lahan, namun belum diketahui secara pasti penggunaan lahan dan tutupan lahan yang apa yang terkonversi menjadi penggunaan lahan lainnya. Salah satu penggunaan lahan yang dikhawatirkan akan terkonversi menjadi lahan terbangun untuk pengembangan pariwisata di Kota Batu adalah tegalan dan kebun yang merupakan penggunaan lahan utama untuk budidaya apel. Oleh karena itu, perlu disusun suatu rencana pengembangan serta konservasi untuk mempertahankan lahan-lahan kebun apel di Kota Batu agar tidak berubah menjadi lahan terbangun seperti permukiman dan objek pariwisata. Identifikasi perubahan penggunaan lahan serta prediksi perubahannya di tahun yang akan datang perlu dilakukan agar dapat disusun rencana untuk pengembangan dan konservasi lahan apel yang ada saat ini di Kota Batu. Tujuan penelitian ini adalah (1) mendelineasi penggunaan lahan di Kota Batu pada tahun 2006, tahun 2012, dan tahun 2018 dan pola perubahannya; dan (2) memprediksi penggunaan lahan di Kota Batu tahun 2030. Hasil dari penelitian ini 
diharapkan dapat menyediakan informasi untuk bahan pertimbangan ulasan pemutakhiran Rencana Tata Ruang Wilayah Kota Batu.

\section{METODE PENELITIAN}

Penelitian dilaksanakan di wilayah Kota Batu, Provinsi Jawa Timur. Secara geografis Kota Batu berada pada posisi $7^{\circ} 44^{\prime} 55,11^{\prime \prime}$ sampai $8^{\circ} 26^{\prime} 35,45^{\prime \prime}$ Lintang Selatan dan $122^{\circ} 17^{\prime} 10,90^{\prime \prime}$ sampai $122^{\circ} 57^{\prime} 11^{\prime \prime}$ Bujur Timur. Wilayah Kota Batu mencakup area seluas $199,17 \mathrm{~km}^{2}$ (Gambar 1).

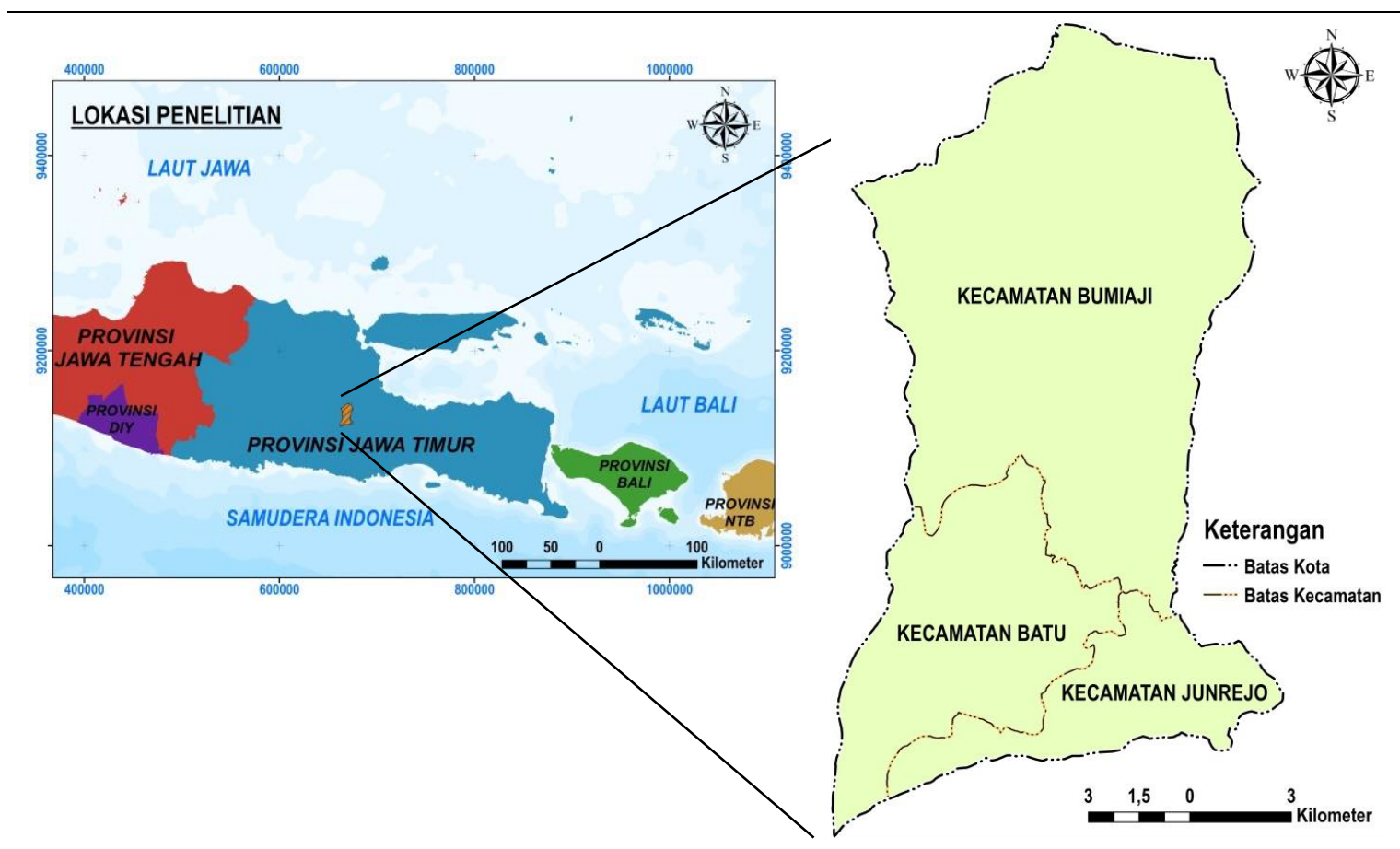

Gambar 1. Lokasi Penelitian

Keterkaitan antara tujuan penelitian, data, metode analisis, dan hasil yang diharapkan secara ringkas disajikan pada Tabel 1.

Tabel 1. Matriks Hubungan antara Tujuan, Jenis Data, Metode dan Hasil

\begin{tabular}{|c|c|c|c|c|c|}
\hline No. & Tujuan & Jenis Data & Sumber Data & $\begin{array}{l}\text { Teknis } \\
\text { Analisis }\end{array}$ & Keluaran \\
\hline 1. & $\begin{array}{l}\text { Mendelineasi } \\
\text { penggunaan lahan di } \\
\text { Kota Batu pada tahun } \\
\text { 2006, tahun 2012, dan } \\
\text { tahun } 2018 \text { dan pola } \\
\text { perubahannya }\end{array}$ & $\begin{array}{l}\text { Citra Sentinel } \\
\text { 2A, Citra Google } \\
\text { Earth }\end{array}$ & $\begin{array}{l}\text { USGS (United } \\
\text { States Geological } \\
\text { Survey) dan } \\
\text { Google Earth }\end{array}$ & $\begin{array}{l}\text { Interpretasi } \\
\text { secara visual, } \\
\text { validasi } \\
\text { dengan } \\
\text { pengecekan } \\
\text { lapangan }\end{array}$ & $\begin{array}{l}\text { Peta Penggunaan } \\
\text { Lahan Kota Batu } \\
\text { Tahun 2006, Tahun } \\
\text { 2012, dan Tahun } \\
\text { 2018 Skala 1: } \\
\text { 25.000 }\end{array}$ \\
\hline 2. & $\begin{array}{l}\text { Memprediksi } \\
\text { penggunaan lahan di } \\
\text { Kota Batu tahun } 2030\end{array}$ & $\begin{array}{l}\text { Penggunaan } \\
\text { lahan Kota Batu, } \\
\text { Pola Ruang Kota } \\
\text { Batu }\end{array}$ & $\begin{array}{l}\text { Keluaran tujuan } \\
\text { 1, Bappeda Kota } \\
\text { Batu }\end{array}$ & $\begin{array}{l}\text { Markov-chain, } \\
\text { Cellular } \\
\text { Automata }\end{array}$ & $\begin{array}{l}\text { Model Perubahan } \\
\text { Penggunaan Lahan } \\
\text { di Kota Batu Tahun } \\
2030\end{array}$ \\
\hline
\end{tabular}




\section{Delineasi Penggunaan Lahan dan Pola Perubahan Penggunaan Lahan}

Delineasi penggunaan lahan dan tutupan lahan di Kota Batu tahun 2006, tahun 2012, dan tahun 2018 dilakukan dengan melakukan interpretasi citra Google Earth dan citra Sentinel 2A. Citra yang telah terkoreksi kemudian diinterpretasi secara visual mengacu pada kunci interpretasi citra yaitu rona, tekstur, pola, ukuran, bentuk, bayangan, asosiasi dan situs (Lillesand et al., 2015). Hasil interpretasi kemudian diverifikasi untuk mengetahui tingkat akurasi interpretasi yang telah dilakukan. Hasil verifikasi dihitung dengan menggunakan overall accuracy dan kappa accuracy. Pengujian hasil interpretasi diharapkan mendapatkan nilai overall accuracy di atas $85 \%$.

Penggunaan lahan yang telah diinterpretasi secara visual selanjutnya divalidasi dengan pengecekan lapangan (Surni et al., 2015; Dani et al., 2017; Murdaningsih et al., 2017; Sadesmesli et al., 2017). Pengecekan lapangan dilakukan dengan observasi pada beberapa titik pengambilan sampel disertai dengan wawancara dengan masyarakat untuk mengetahui informasi mengenai riwayat jenis penggunaan lahan.

\section{Prediksi Penggunaan Lahan}

Pemodelan prediksi penggunaan lahan dilakukan dengan pendekatan metode Markov Chain dan Cellular Automata (CA). El-Hallaq dan Habboub (2015) menjelaskan proses Markov sebagai keadaan sistem pada waktu kedua dapat diprediksi dengan keadaan sistem pada waktu pertama dengan memberikan matriks probabilitas transisi dari masing-masing kelas penutupan lahan untuk setiap kelas penutupan lahan lainnya. Matriks probabilitas dan area transisi didapatkan dengan menggunakan input penggunaan lahan antara tahun 2006 dengan 2012 dan tahun 2006 dengan tahun 2018. Metode ini digunakan untuk mengetahui pola perubahan dan kemungkinan perubahan antara satu penggunaan lahan ke penggunaan lahan lain dalam rentang waktu tertentu.

Model Markov-CA menggunakan filter matriks berukuran 5 x 5 yang merupakan penerjemahan dari konsep ketetanggaan. Ukuran ini diartikan bahwa perubahan penggunaan lahan pada piksel pusat dipengaruhi oleh nilai 24 piksel tetangganya. Filter matriks ini sifatnya bergerak secara horizontal atau vertikal dalam melakukan analisis ketetanggaan pada suatu peta raster. Prediksi perubahan tahun 2018 dilakukan sebagai proses validasi model berdasarkan data penggunaan lahan tahun 2006 dan 2012 dalam melakukan simulasi perubahan penggunaan lahan, kemudian baru dilakukan prediksi penggunaan lahan tahun 2030.

\section{HASIL DAN PEMBAHASAN}

\section{Delineasi Penggunaan Lahan Kota Batu}

Hasil interpretasi citra Sentinel 2A tahun 2018 secara visual memberikan nilai overall accuracy sebesar $88,5 \%$. Nilai tersebut sudah memenuhi persyaratan validasi hasil interpretasi sehingga peta penggunaan lahan yang dihasilkan layak untuk digunakan dalam penelitian ini. Menurut Jensen (1996), sebuah peta penggunaan atau tutupan lahan hasil interpretasi dapat dikatakan baik jika memiliki nilai akurasi lebih dari 85\%. Tabel 2 menunjukkan penggunaan lahan di Kota Batu berdasarkan hasil interpretasi tahun 2006, tahun 2012, dan tahun 2018 serta perubahannya pada Tabel 3 dan Gambar 2.

Penggunaan lahan di Kota Batu didominasi oleh hutan dan tegalan. Wilayah utara Kota Batu merupakan wilayah kawasan Taman Hutan Raya Raden Soerjo. Hutan menyebar hingga wilayah barat dan barat daya Kota Batu. Semak/belukar diidentifikasi berada pada kawasan Taman Hutan Raya. Kawasan lahan terbangun menyebar dan berkembang pesat di pusat wilayah dan diikuti dengan tegalan di sekitarnya. Wilayah timur Kota Batu di dominasi oleh kebun, serta sawah berada di wilayah tenggara Kota Batu. 
Tabel 2. Penggunaan Lahan Kota Batu Tahun 2006, 2012, dan 2018

\begin{tabular}{|c|c|c|c|c|c|c|c|}
\hline \multirow{3}{*}{ No. } & \multirow{3}{*}{$\begin{array}{c}\text { Penggunaan } \\
\text { Lahan }\end{array}$} & \multicolumn{6}{|c|}{ Luas } \\
\hline & & \multicolumn{2}{|c|}{ Tahun 2006} & \multicolumn{2}{|c|}{ Tahun 2012} & \multicolumn{2}{|c|}{ Tahun 2018} \\
\hline & & ha & $\%$ & ha & $\%$ & ha & $\%$ \\
\hline 1. & Hutan & $9.000,8$ & 45,19 & $8.780,4$ & 44,09 & $7.995,7$ & 40,15 \\
\hline 2. & Kebun & 2.5 & 12,86 & $2.480,0$ & 12 & $2.322,1$ & 11,66 \\
\hline 3. & Lahan Terba & $2.193,8$ & 11,01 & $2.786,0$ & 13,99 & $3.229,6$ & 16,22 \\
\hline 4. & Sawah & 206,3 & 1,04 & 197,8 & 0,99 & 112,4 & 0,56 \\
\hline 5. & Semak/Belukar & 863,6 & 4,34 & $1.100,4$ & 5,53 & $1.894,1$ & 9,51 \\
\hline 6. & Lahan Terbuka & 271,9 & 1,37 & 248,6 & 1,25 & 261,4 & 1,31 \\
\hline \multirow[t]{2}{*}{7.} & Tegalan & $4.818,6$ & 24,19 & $4.323,5$ & 21,71 & $4.101,4$ & 20,59 \\
\hline & $\begin{array}{l}\text { Luas Keseluruhan } \\
\text { (ha atau \%) }\end{array}$ & $19.916,7$ & 100,0 & $19.916,7$ & 100,0 & $19.916,7$ & 100,0 \\
\hline
\end{tabular}

Tabel 3. Perubahan Penggunaan Lahan Kota Batu Tahun 2006, 2012, dan 2018

\begin{tabular}{|c|c|c|c|c|c|c|c|}
\hline \multirow{3}{*}{ No. } & \multirow{3}{*}{ Penggunaan Lahan } & \multicolumn{6}{|c|}{ Perubahan Luas } \\
\hline & & \multicolumn{2}{|c|}{$2006-2012$} & \multicolumn{2}{|c|}{$2012-2018$} & \multicolumn{2}{|c|}{$2006-2018$} \\
\hline & & ha & $\%$ & ha & $\%$ & ha & $\%$ \\
\hline 1. & Hutan & $-220,4$ & $-1,11$ & $-784,7$ & $-3,94$ & $-1.005,1$ & $-5,05$ \\
\hline 2. & Kebun & $-81,7$ & $-0,41$ & $-157,9$ & $-0,79$ & $-239,6$ & $-1,20$ \\
\hline 3. & Lahan Terbangun & 592,2 & 2,97 & 443,6 & 2,23 & $1.035,8$ & 5,20 \\
\hline 4. & Sawah & $-8,5$ & $-0,04$ & $-85,4$ & $-0,43$ & $-94,0$ & $-0,47$ \\
\hline 5. & Semak/Belukar & 236,8 & 1,19 & 793,7 & 3,99 & $1.030,5$ & 5,17 \\
\hline 6. & Lahan Terbuka & $-23,2$ & $-0,12$ & 12,7 & 0,06 & $-10,5$ & $-0,05$ \\
\hline 7. & Tegalan & $-495,1$ & $-2,49$ & $-222,0$ & $-1,11$ & $-717,2$ & $-3,60$ \\
\hline
\end{tabular}

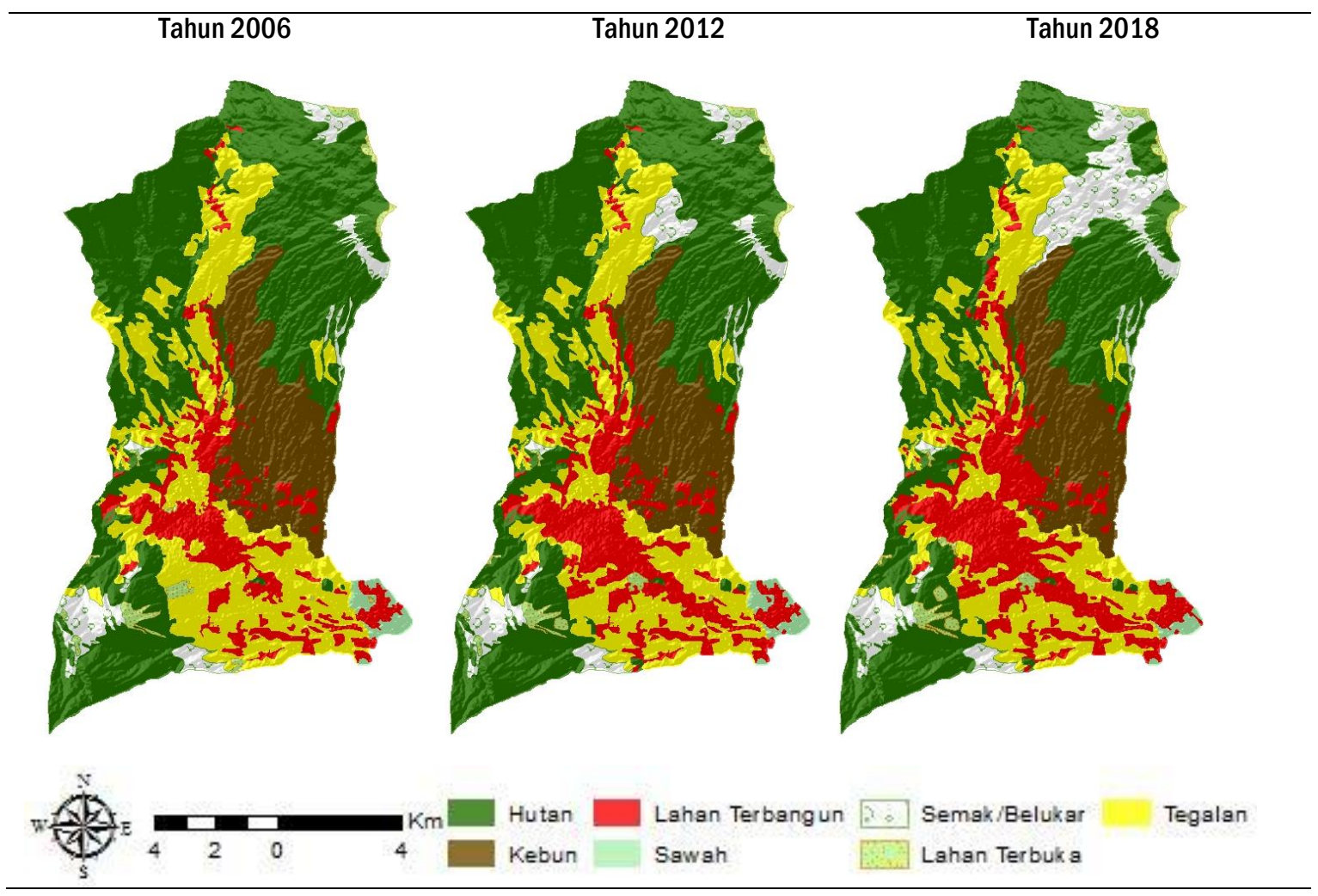

Gambar 2. Perubahan Penggunaan Lahan Kota Batu Tahun 2006, 2012, 2018

Periode tahun 2006 hingga tahun 2018 menunjukkan tren penggunaan lahan hutan di Kota Batu turun mencapai 5,0\% atau berkurang 1.005,1 ha. Adanya penurunan luas 
hutan tersebut mengindikasikan adanya perubahan penggunaan lahan hutan menjadi nonhutan dan adanya kerusakan lahan hutan. Hal tersebut dapat dilihat dari adanya penurunan kerapatan vegatasi yang teridentifikasi pada saat interpretasi citra satelit.

Penggunan lahan kebun di Kota Batu pada umumnya digunakan sebagai lokasi untuk budidaya apel dan jeruk. Luas penggunaan lahan kebun di Kota Batu menunjukkan tren yang menurun, namun tetap relatif stabil dengan perubahan sebesar $1,2 \%$ atau berkurang 239,6 ha pada periode tahun 2006 hingga tahun 2018. Lahan kebun memberikan nilai ekonomi yang lebih tinggi dibandingkan lahan pertanian lainnya seperti sawah atau tegalan terhadap ekonomi masyarakat sekitar. Wilayah yang menjadi lokasi budidaya apel dan jeruk berada wilayah timur Kota Batu yaitu Kecamatan Bumiaji. Namun, masyarakat juga memanfaatkan lahan tegalan sebagai lahan budidaya apel dan jeruk.

Penggunan lahan tegalan di Kota Batu pada umumnya digunakan sebagai lokasi untuk budidaya tanaman hortikultura seperti kentang, wortel, dan kubis. Luas penggunaan lahan tegalan di Kota Batu menunjukkan tren yang menurun dengan perubahan sebesar $3,6 \%$ atau berkurang 717,2 ha pada periode tahun 2006 hingga tahun 2018. Wilayah Kota Batu didimonasi oleh penggunaan lahan tegalan dikarenakan kondisi fisik wilayahnya yang agak landai hingga agak curam membuat masyarakat lebih mudah memanfaatkannya sebagai lahan tegalan dibandingkan sawah.

Lahan terbangun dalam hasil interpretasi merupakan penggabungan dari permukiman, gedung, pabrik maupun industri yang terdapat di Kota Batu. Luas lahan terbangun di Kota Batu mengalami peningkatan yang cukup tinggi selama periode tahun 2006 hingga tahun 2018 yaitu sebesar 5,2\% atau bertambah 1035,8 ha. Perubahan penggunaan lahan menjadi lahan terbangun di Kota Batu dominan terjadi di bagian pusat Kota Batu. Luas lahan sawah di Kota Batu mengalami tren penurunan pada periode tahun 2006 hingga tahun 2018. Penurunan luas sawah di Kota Batu yaitu sebesar 0,5\% atau berkurang 94,0 ha.

Semak/belukar sering diartikan sebagai wilayah transisi, umumnya dari hutan sebelum dimanfaatkan oleh masyarakat yang tinggal di sekitarnya sehingga mempunyai nilai ekonomi. Semakin banyak semak/belukar yang terindentifikasi maka peluang lahan tersebut akan terkonversi akan semakin besar. Hal ini dapat dilihat dari luasan semak belukar yang menujukkan tren meningkat. Kota Batu mengalami peningkatan luas semak/belukar yang cukup tinggi sebesar 5,2\% atau bertambah 1.030,5 ha. Luas Lahan Terbuka di Kota Batu mengalami tren penurunan pada periode tahun 2006 hingga tahun 2018. Penurunan luas lahan terbuka di Kota Batu yaitu sebesar $0,1 \%$ atau berkurang 10,5 ha.

\section{Pola Perubahan Penggunaan Lahan di Kota Batu}

Arah perubahan penggunaan lahan didapatkan dari lahan yang berubah pada periode tahun 2006 - 2012 dan 2012 - 2018. Perubahan yang terjadi menggambarkan arah proses pemanfaatan lahan dan pola perubahannya. Pola perubahan penggunaan lahan yang dominan terjadi di Kota Batu periode tahun 2006 - 2018 ditunjukkan pada Tabel 4 dan Gambar 3. Perubahan penggunaan lahan yang terjadi di Kota Batu pada periode tahun 2006 hingga tahun 2018 memperlihatkan adanya perubahan yang dominan dari lahan pertanian terutama tegalan dan kebun menjadi lahan terbangun. Perubahan tegalan dan kebun menjadi lahan terbangun terjadi sebesar 977,1 ha. Pola perubahan terbesar adalah perubahan lahan tegalan menjadi lahan terbangun dengan luasan 441,6 ha untuk pola tegalan - lahan terbangun - lahan terbangun dan 279,7 ha untuk pola tegalan - tegalan lahan terbangun. Perubahan kebun menjadi lahan terbangun dengan pola kebun - kebun lahan terbangun memiliki luasan 146,0 ha dan pola kebun - lahan terbangun - lahan terbangun memiliki luasan 78,4 ha. 
Tabel 4. Pola Perubahan Penggunaan Lahan di Kota Batu

\begin{tabular}{rlllr}
\hline No. & $\begin{array}{c}\text { Penggunaan Lahan } \\
\text { Tahun 2006 }\end{array}$ & $\begin{array}{c}\text { Penggunaan Lahan } \\
\text { Tahun 2012 }\end{array}$ & $\begin{array}{c}\text { Penggunaan Lahan } \\
\text { Tahun 2018 }\end{array}$ & Luas (ha) \\
\hline 1. & Sawah & Sawah & Lahan Terbangun & 21,4 \\
2. & Sawah & Sawah & Tegalan & 67,6 \\
3. & Sawah & Lahan Terbangun & Lahan Terbangun & 8,5 \\
4. & Lahan Terbuka & Lahan Terbangun & Lahan Terbangun & 60,4 \\
5. & Lahan Terbuka & Lahan Terbuka & Lahan Terbangun & 2,0 \\
6. & Lahan Terbuka & Lahan Terbuka & Semak/Belukar & 19,4 \\
7. & Tegalan & Lahan Terbangun & Lahan Terbangun & 441,6 \\
8. & Tegalan & Tegalan & Lahan Terbangun & 279,7 \\
9. & Tegalan & Tegalan & Lahan Terbuka & 15,9 \\
10. & Tegalan & Tegalan & Kebun & 3,4 \\
11. & Tegalan & Lahan Terbuka & Lahan Terbangun & 1,4 \\
12. & Tegalan & Lahan Terbuka & Lahan Terbuka & 32,8 \\
13. & Hutan & Lahan Terbuka & Lahan Terbuka & 20,0 \\
14. & Hutan & Semak/Belukar & Semak/Belukar & 236,8 \\
15. & Hutan & Hutan & Lahan Terbangun & 6,5 \\
16. & Hutan & Hutan & Lahan Terbuka & 19,7 \\
17. & Hutan & Hutan & Semak/Belukar & 774,6 \\
18. & Kebun & Lahan Terbangun & Lahan Terbangun & 78,4 \\
19. & Kebun & Kebun & Lahan Terbangun & 146,0 \\
\hline
\end{tabular}

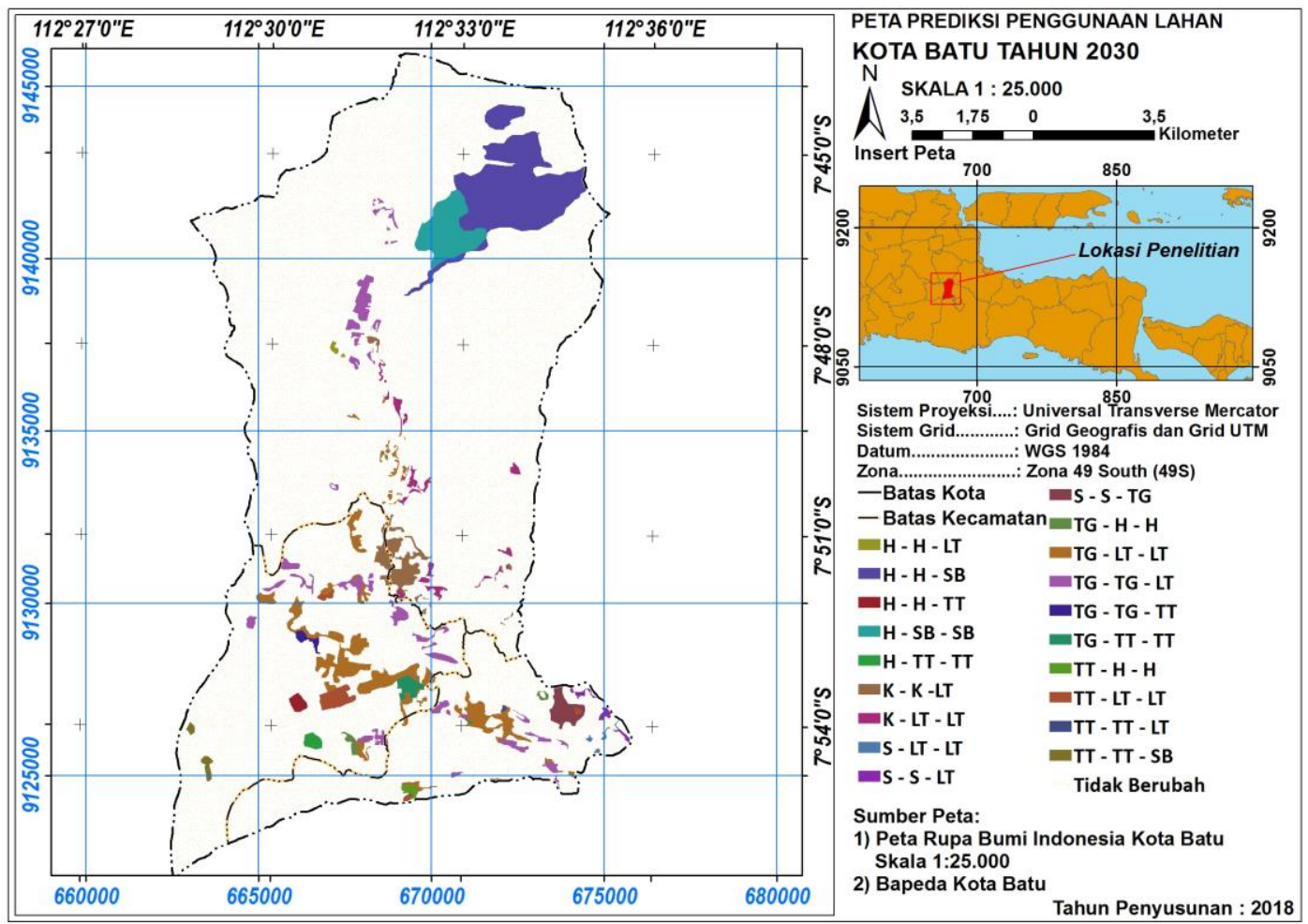

Keterangan: $H=$ hutan, $K=$ =kebun, $L T=$ lahan terbangun, $S=$ sawah, $S B=$ semak/belukar, $T T=$ lahan terbuka, Tg=tegalan

\section{Gambar 3. Pola Perubahan Penggunaan Lahan Kota Batu Tahun 2006, 2012, 2018}

Penelitian Dwinanto et al. (2016) dan Yudarwati et al. (2016) menunjukkan adanya kecenderungan perubahan penggunaan lahan yang sama yaitu perubahan lahan hutan menjadi non-hutan, terutama lahan terbangun. Priyanto (2017) menyatakan bahwa adanya 
kemenarikan lahan untuk terkonversi menjadi lahan terbangun dikarenakan oleh tingginya nilai ekonomi dari suatu lahan terbangun jika dibandingkan dengan penggunaan lahan lainnya. Alih fungsi lahan berlangsung dari aktivitas dengan land rent yang lebih rendah ke aktivitas-aktivitas yang land rent yang lebih tinggi. Alih fungsi lahan merupakan bentuk dan konsekuensi logis dari perkembangan potensial land rent di suatu lokasi. Secara teoritis masalah konversi timbul karena nilai land rent di dalam mekanisme pasar tidak mencerminkan seluruh nilai barang, jasa dan biaya-biaya yang tidak ditransaksikan di pasar, seperti nilai dari jasa-jasa lingkungan (Rustiadi et al., 2011). Konversi atau pergeseran penggunaan lahan berlangsung secara searah dan bersifat irreversible (tidak dapat balik), seperti lahan-lahan hutan yang sudah dikonversi menjadi lahan pertanian umumnya sulit untuk dihutankan kembali. Demikian juga, sawah yang terkonversi menjadi perumahan atau kawasan terbangun lainnya hampir tidak mungkin kembali menjadi sawah.

\section{Prediksi Perubahan Penggunaan Lahan di Kota Batu Tahun 2030}

Prediksi penggunaan lahan tahun 2018 diperoleh berdasarkan kecenderungan perubahan penggunaan lahan tahun 2006 dan 2012 dengan menjalankan model simulasi Cellular Automata-Markov (CA Markov). Tabel 5 dan Gambar 4 memperlihatkan hasil prediksi penggunaan lahan tahun 2030 di Kota Batu. Pada tahun 2030 diprediksi akan terjadi penurunan luas pada penggunaan lahan hutan seluas 889,1 ha $(4,46 \%)$, kebun seluas 218,9 ha (1,10\%), sawah seluas 51,2 ha (),26\%), lahan terbuka seluas 47,6 ha $(0,26 \%)$, dan tegalan seluas 595,9 ha $(2,99 \%)$. Sebaliknya pada tahun 2030 diprediksi akan terjadi peningkatan luas terbesar pada penggunaan lahan semak/belukar sebesar 918,8 ha (4,61\%), kemudian lahan terbangun sebesar 883,9 ha $(4,44 \%)$. Penelitian prediksi perubahan penggunaan lahan di kota-kota di Indonesia hampir selalu menunjukkan adanya pengurangan lahan hutan dan peningkatan lahan terbangun. Sebagai contoh, Zahrotunnisa dan Wicaksono (2017) memprediksi peningkatan lahan terbangun di Kota Bogor di tahun 2031 memiliki peluang ekspansi sebesar 0,3241.

Tabel 5. Prediksi Luas dan Perubahan Penggunaan Lahan di Kota Batu

\begin{tabular}{|c|c|c|c|c|c|c|c|}
\hline \multirow{3}{*}{ No. } & \multirow{3}{*}{ Penggunaan Lahan } & \multicolumn{6}{|c|}{ Luas } \\
\hline & & \multicolumn{2}{|c|}{ Tahun 2018} & \multicolumn{2}{|c|}{ Tahun 2030} & \multicolumn{2}{|c|}{ Perubahan } \\
\hline & & ha & $\%$ & ha & $\%$ & ha & $\%$ \\
\hline 1. & Hutan & $7.995,7$ & 40,1 & $7.106,6$ & 35,7 & $-889,10$ & $-4,46$ \\
\hline 2. & Kebun & $2.322,1$ & 11,7 & $2.103,2$ & 10,6 & $-218,90$ & $-1,10$ \\
\hline 3. & Lahan Terbangun & $3.229,6$ & 16,2 & $4.113,4$ & 20,7 & 883,90 & 4,44 \\
\hline 4. & Sawah & 112,4 & 0,6 & 61,2 & 0,3 & $-51,20$ & $-0,26$ \\
\hline 5. & Semak/Belukar & $1.894,1$ & 9,5 & $2.812,9$ & 14,1 & 918,80 & 4,61 \\
\hline 6. & Lahan Terbuka & 261,4 & 1,3 & 213,8 & 1,1 & $-47,60$ & $-0,24$ \\
\hline \multirow[t]{2}{*}{7.} & Tegalan & $4.101,4$ & 20,6 & 3505,5 & 17,6 & $-595,90$ & $-2,99$ \\
\hline & Luas Keseluruhan (ha) & $19.916,7$ & 100,0 & $19.916,7$ & 100,0 & $19.916,7$ & 100,0 \\
\hline
\end{tabular}

Perubahan penggunaan lahan menjadi lahan terbangun umumnya akan menyisakan lahan-lahan yang secara alami lebih rentan bencana. Pontoh dan Sudrajat (2005) menyatakan bahwa perubahan penggunaan lahan dari ruang terbuka hijau menjadi lahan terbangun akan berpengaruh besar terhadap lingkungan terutama limpasan dan resapan airnya. Van Noordwijk et al. (2004) menyatakan bahwa tutupan lahan oleh pohon dengan segala bentuk dapat mempengaruhi aliran air dalam beberapa tahap seperti intersepsi, perlindungan agregat tanah, infiltrasi, serapan air serta drainase lanskap. Sehingga dampak dari adanya konversi dapat dilihat dari kombinasi dan interaksi dari berbagai proses tersebut. Utaya (2008) menyatakan bahwa perubahan penggunaan lahan dapat merubah sifat biofisik tanah dan mengakibatkan menurunnya kemampuan tanah dalam meresapkan air. Prediksi perubahan penggunaan lahan di Kota Batu pada tahun 2030 menunjukkan 
peningkatan luas lahan terbangun dan semak belukar, diikuti oleh penurunan luas hutan. Lahan hutan diprediksi turun menjadi $7.106,6$ ha $(35,7 \%)$, sementara lahan terbangun meningkat menjadi $4.113,4$ ha $(20,7 \%)$. Jika perubahan ini terus terjadi dan dibiarkan tanpa kendali, dikhawatirkan akan membahayakan kondisi lingkungan di Kota Batu seperti akan meningkatnya limpasan air permukaan dan resiko bencana longsor.

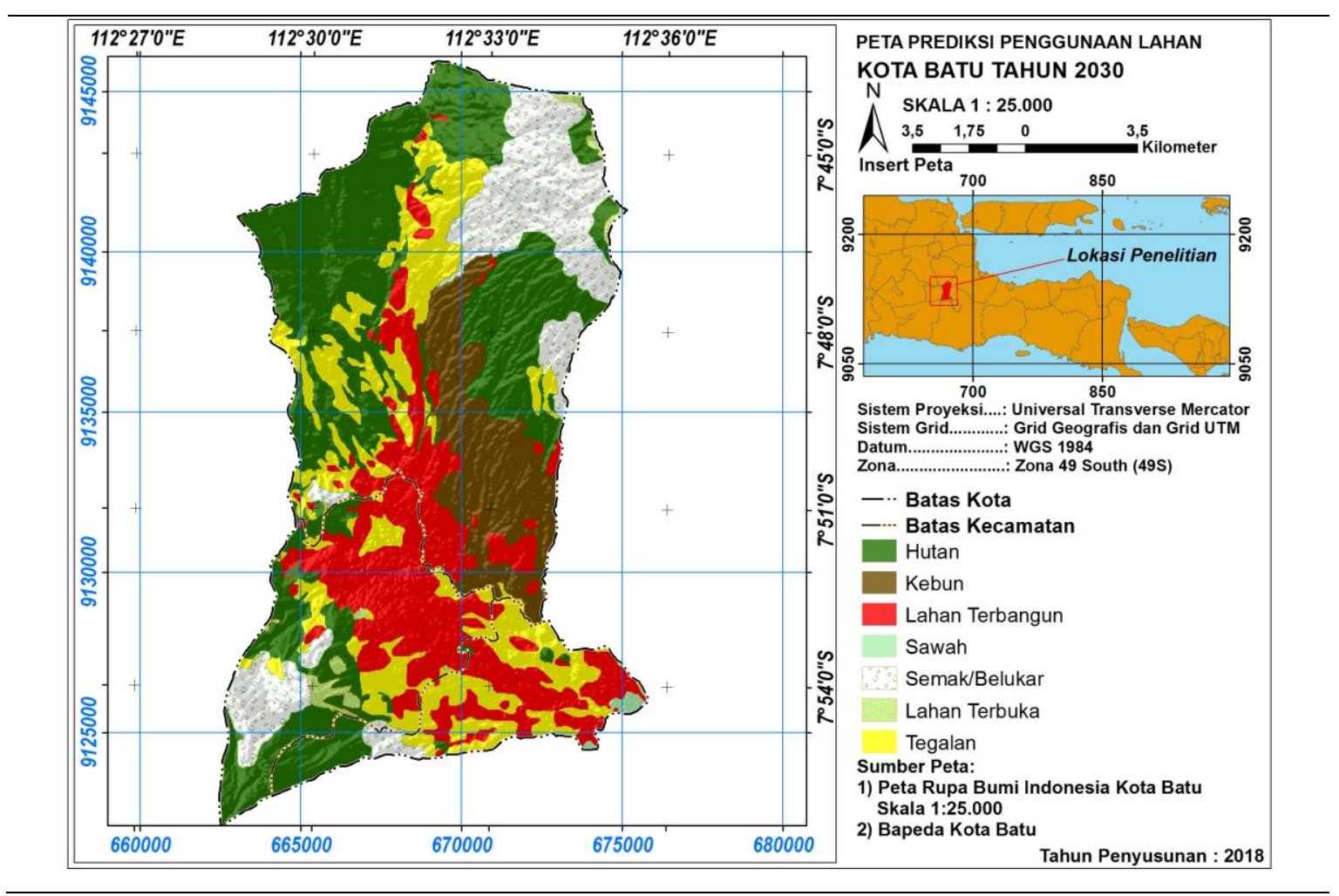

Gambar 4. Prediksi Penggunaan Lahan Kota Batu Tahun 2030

\section{KESIMPULAN}

Perubahan penggunaan lahan yang terjadi di Kota Batu tahun 2006 hingga tahun 2018 didominasi oleh perubahan hutan menjadi non-hutan $(5,0 \%)$, dan lahan pertanian menjadi lahan terbangun $(5,2 \%)$. Perubahan terbesar terjadi pada penggunaan lahan hutan menjadi semak/belukar, dan tegalan menjadi lahan terbangun. Prediksi perubahan penggunaan lahan pada tahun 2030 di Kota Batu juga menunjukkan adanya penurunan luas hutan menjadi $7.106,6$ ha $(35,7 \%)$, dan adanya peningkatan lahan terbangun menjadi 4.ii3,4 ha (20,7\%). Perubahan tersebut akan berdampak pada meningkatnya resiko bencana longsor dan ketersediaan lahan pengembangan apel di Kota Batu. Tegalan merupakan salah satu lahan yang umumnya digunakan sebagai lahan budidaya apel.

Untuk menjaga ketersediaan lahan pengembangan apel sebagai icon di Kota Batu, lahan pertanian terutama kebun dan tegalan diarahkan untuk dilindungi atau dikonservasi, serta semak belukar dan lahan terbuka di Kota Batu diarahkan menjadi lahan potensial untuk pengembangan apel.

\section{DAFTAR PUSTAKA}

[BPS] Badan Pusat Statistik. 2017. Kota Batu Dalam Angka Tahun 2017. Batu (ID): Badan Pusat Statistik Kota Batu. https://batukota.bps.go.id/publication/2017/08/11/854e67badaf27f24c61b2ae8/kota-batudalam-angka-2017.html 
Chen, J., Gong, P., He, C., Luo, W., Tamura, M., \& Shi, P.J. 2002. Assessment of the Urban Development Plan of Beijing by Using CA-based Urban Growth Model. Photogrametric Engineering \& Remote Sensing. 68(10): 1063-1071. http://citeseerx.ist.psu.edu/viewdoc/download?doi=10.1.1.471.1587\&rep=rep1\&type=pdf

Dani, E.T., Sitorus, S.R.P., \& Munibah, K. 2017. Analisis Penggunaan Lahan dan Arahan Pengendalian Pemanfaatan Ruang di Kabupaten Bogor. Tataloka. 19(1): $40-52$. https://ejournal2.undip.ac.id/index.php/tataloka/article/view/757

Dwinanto, A.A.P., Munibah, K., \& Sudadi, U. 2016. Model Perubahan dan Arahan Penggunaan Lahan untuk Mendukung Ketersediaan Beras di Kabupaten Brebes dan Kabupaten Cilacap. Tataloka. 18(3): 157-171. https://ejournal2.undip.ac.id/index.php/tataloka/article/view/688

E1-Hallaq, M.A. \& Habboub, M.O. 2015. Using Cellular Automata-Markov Analysis and Multi Criteria Evaluation for Predicting the Shape of the Dead Sea. Advances in Remote Sensing. 4: 83-95. DOI: 10.4236/ars.2015.41008

Jensen, J.R. 1996. Introductory Digital Image Processing: A Remote Sensing Perspective. $2^{\text {nd }}$ Edition. New Jersey (US): Prenctice Hall.

Lillesand, T., Kiefer, R.W., \& Chipman, J. 2015. Remote Sensing and Imange Interpretation. $7^{\text {th }}$ Edition. New Jersey (US): John Wiley \& Sons Inc.

Manson, S. 2006. Land Use in the Southern Yucatán in Peninsular Region of Mexico: Scenarios of Population and Institutional Change. Computers, Environment and Urban Systems. 30(3): 230-253. DOI:10.1016/j.compenvurbsys.2005.01.009

McConnel, W.J. 2001. Preface in Report and Review of International Workshop of Agent Based Models of Land Use and Land Cover Change. pp: xi-xiv. California (US): LUCC Focus 1 Office.

Murdaningsih, Widiatmaka, Munibah, K., \& Ambarwulan, W. 2017. Analisis Spasial Perubahan Penggunaan Lahan Pertanian untuk Mendukung Kemandirian Pangan di Kabupaten Indramayu. Majalah Ilmiah Globe. 19(2): 175-184. http://jurnal.big.go.id/index.php/GL/article/view/604

Pontoh, N.K. \& Sudrajat, D.J. 2005. Hubungan Perubahan Penggunaan Lahan dengan Limpasan Air Permukaan: Studi Kasus Kota Bogor. Jurnal Perencanaan Wilayah dan Kota. 16(3): 44-56. http://journals.itb.ac.id/index.php/jpwk/article/download/4271/2315

Priyanto, D. 2017. Spatial Modelling on Land Attractiveness for Sustainable Development in Surabaya City [Tesis]. Bogor (ID): Institut Pertanian Bogor.

Rustiadi, E., Saefulhakim, S., \& Panuju. D.R. 2011. Perencanaan dan Pengembangan Wilayah. Jakarta (ID): Crestpent Press dan Yayasan Pustaka Obor Indonesia.

Sadesmesli, I., Baskoro, D.P.T., \& Pravitasari, A.E. 2017. Daya Dukung Lahan dalam Perencanaan Tata Ruang Wilayah (Studi Kasus Kabupaten Blitar, Jawa Timur). Tataloka. 19 (4): 266-279. DOI: https://doi.org/10.14710/tataloka.19.4.266-279

Surni, Baja, S., \& Arsyad, U. 2015. Dinamika perubahan penggunaan lahan, penutupan lahan terhadap hilangnya biodiversitas di DAS Tallo, Sulawesi Selatan. Pros Sem Nas Masy Biodiv Indonesia. 1 (5): 10501055.

Utaya, S. 2008. Pengaruh Perubahan Penggunaan Lahan Terhadap Sifat Biofisik Tanah dan Kapasitas Infiltrasi $\begin{array}{llllll}\text { di Kota Malang. } & \text { Forum } & \text { Geografi. } & 22 & \text { (2):99 } & -\end{array} 112$. http://journals.ums.ac.id/index.php/fg/article/download/4986/3309

van Noordwijk, M., Agus, F., Suprayogo, D., Hairiah, K., Pasya, G., Verbist, B., \& Farida. 2004. Peranan Agroforestri dalam Mempertahankan Fungsi Hidrologi Daerah Aliran Sungai (DAS). Agrivita. 26(1): 1 8. https://www.academia.edu/9040056/PERANAN_AGROFORESTRI_DALAM_MEMPERTAHAN KAN_FUNGSI_HIDROLOGI_DAERAH_ALIRAN_SUNGAI_DAS

Yu, H., Ha, Z., \& Pan, X. 2010. Wetlands Shrink Simulation Using Cellular Automata: A Case Study in Sanjiang Plain China. Procedia Environmental Sciences. 2: 225-233. Doi: 10.1016/j.proenv.2010.10.027

Yudarwati, R., Sitorus, SRP., \& Munibah, K. 2016. Arahan Pengendalian Perubahan Penggunaan Lahan Menggunakan Markov- Cellular Automata di Kabuaten Cianjur. Tataloka. 18 (4): 211 - 221. https://ejournal2.undip.ac.id/index.php/tataloka/article/view/954

Zahrotunnisa, S. \& Wicaksono, P. 2017. Prediksi Spasial Perkembangan Lahan Terbangun Melalui Pemanfaatan Citra Landsat Multitemporal di Kota Bogor. JOIN. 2 (1): $30 \quad-\quad 35$. https://www.researchgate.net/publication/318118179_Prediksi_Spasial_Perkembangan_Lahan_Terba ngun_Melalui_Pemanfaatan_Citra_Landsat_Multitemporal_di_Kota_Bogor 